\title{
The Analysis of Wini Beach Development as Coastal Tourism in North Central Timor Regency
}

\author{
Ariance Ana Lasibey*, Boiris Milyardo \\ Tourism Department \\ State Polytechnic of Kupang \\ East Nusa Tenggara Province, Indonesia \\ *rinlasibey@gmail.com, boiris.milyardo@gmail.com
}

\begin{abstract}
This research aims to analyze tourism indicators, weaknesses, opportunities, and threats, and to determine the right strategy that can be developed in Wini Beach. This research uses combination methods with concurrent triangulation and SWOT. This research took 30 Respondents. Data Analysis gain that the environmental and ecological variables score results is a clash, can be ignored that the understanding of the environment and ecology at Wini Beach was not good enough. The economic and development variables score gain with quite good on average, so it can be ignored that Wini Beach has not implemented this variable. The social and cultural variables score gain and average in the category is quite good, so it can be ignored that Wini Beach has used a strategy on this variable. The variable of tourism value gain is contradictory so that it can be denied that Wini Beach is good enough in implementing this variable. Furthermore, the management and policy variables obtained an average score in the good category so that it can be ignored that Wini Beach has implemented these variables. In the climate analysis variable, the average category is not good, so that the strategy has not been implemented on this variable. Strategies that can be carried out such as optimizing the coastal tourism, developing management professionalism, developing human resources in the tourism sector, building ecosystem quality through cooperation, developing coastal ecosystem conservation programs, increasing promotion expansion, and integrating development with sustainable and controlled maintenance.
\end{abstract}

Keywords—analysis development, coastal tourism

\section{INTRODUCTION}

Based on data compiled by the Kefamenanu Regency/City Tourism Office during 2018 and 2019 there were around 158,181 tourists visiting tourist sites in Kefamenanu Regency / City, consisting of 102,182 domestic tourists and 55,999 foreign tourists [1]. Currently, coastal tourism indicators have not been identified on Wini Beach as a whole. This can be seen through inadequate infrastructure and facilities. It is very important to note that accessibility is one important factor in increasing tourist arrivals. Apart from infrastructure and facilities, there are still many other indicators of coastal tourism that must be identified so that the problems and solutions can be identified. As is the case with the coastal environment of Wini Beach which is not good and has an impact on the decline in the quality of this beach tourism object so that it can cause a lack of interest in tourists traveling around this beach. The lack of clean water supply also makes the coastal environment looks a little rundown. Also, the ability of coastal communities in the management and utilization of natural, economic, and socio-cultural resources is still low, so the management and development of coastal tourism on Wini Beach is not optimal. This can be seen from the knowledge and skills they have. Their expertise is usually only as fishermen. The potential for coastal tourism on Wini Beach should be able to improve the standard of living of the surrounding community if managed properly. The tourism potential in the City of Kefamenan is famous for its coastal tourism objects and culture so that many tourist areas along Wini Beach can be developed such as coastal tourism on Wini Beach, Tanjung Bastian, and Idola Beach to product development in the tourism sector which is directed at developing coastal tourism objects, forest tourism, water tourism, and cultural tourism. The beaches around Timor Tengah Utara district offer a fun vacation spot for travelers so they can enjoy the beauty of the beach view and the State Border Post Building which was built very majestically and directly borders with a neighboring country, namely Timor Leste. Even though Wini Beach has long been a tourist attraction, the obstacles faced are the lack of socialization and promotion and the absence of optimal development of tourism destinations on this coast. Besides, the limited support of facilities and infrastructure that support coastal tourism activities also results in a decrease in the attractiveness of tourism objects on this beach. Even though this beach tourism object has a natural tourist attraction that can be developed into superior tourism so that it can motivate tourists to visit. Based on some of the problems above, Wini Coastal tourism must be developed, managed, and marketed by stakeholders so that the creation of superior coastal tourism will have an impact on the progress of the tourism industry in North Central Timor Regency which of course must be seen from the identification of each coastal tourism indicator. Tourists can look for something rich, imaginative, and meaningful [2]. 


\section{LITERATURE REVIEW}

\section{A. Coastal Tourism}

Monavari [3], states that coastal tourism is: "Coastal and marine tourism includes recreational activities that involve traveling far from the residence of someone who hosts or focuses on the marine environment and / or coastal areas". That is, Coastal Tourism includes recreational activities that involve traveling away from the residence of someone who is hosting or focusing on the coastal zone environment.

\section{B. Coastal Tourism Indicators}

Coastal tourism indicators can be used as a guide to show the most important issues regarding the development and development of coastal tourism on the coast [2].

The dimensions and indicators of coastal tourism according to Timmerman [2] as follows:

- Environment and Ecology includes: Ecological Planning, Pollution Prevention, Environmental Maintenance, Ecological Restoration Systems, Environmental Monitoring Systems, and Landscape Diversity

- Economy and Development includes: Local Job Opportunities, Economic Subsidies, Association Operations Development, and Creative Industry Planning

- Society and Culture includes: Quality of Infrastructure, Promotion of Conservative Concepts, Protection of Local Culture and Training of Tourism Human Resources

- Tourism Value Creation includes: Quality of Tourism Facilities, Tour Guide Services, Service Quality, Customer Experience Value, and Quality of Creative Tourism Activities

- Management and Policies include: Comprehensive Regulation Formulation, Control Measures, Professional Management Human Resources, Management Task Planning, Special Administrative Units, Budget Allocation and Local Participation Policy

- Climatic Conditions include: Seasonal and Hurricane Factors

\section{Benefits of Coastal Tourism}

Larsen [4] stated that at the international level, the benefits of coastal tourism depend on communication and cooperation between countries according to a complex network of laws, regulations, and policies. Whereas at the national level, generally following the rules governing working conditions including labor holidays and income levels, social welfare, education, and others [5]. The organization of these two levels enjoys tourism activities, socio-cultural, economic, political environmental benefits, and so on. In this way, guidelines and strategies can be designed with a long-term perspective for the benefits of tourism and environmental protection [6].

\section{Coastal Tourism Development}

Sugiyono [7] suggest that the coast consists of two separate and evolving ecosystems, built around the part that humans inhabit and other nature that comes with its elements and resources. Meanwhile, Cahyadinata [8] stated the several types of coastal tourism activities are sunbathing, playing sand, and beach sports around the coast. The Commonwealth Coastal Action Program [9] states that coastal tourism development is a tourism development that takes into account conservation areas and the changes in ecological communities that result from it, including protecting wildlife and maintaining the quality of life in the environment for the future generations.

Creswell [10] The results show that the main strategy for implementing sustainable coastal tourism in the study area must be based on a conservative approach. After the improvement of these conditions, the development strategy can be executed in the coastal zone [3]. Strategy propositions are formulated using SWOT analysis to develop contextual strategies taking into account internal and external conditions. Based on several conditions found from the interview, a strategy can be categorized as a type of turnaround because it is characterized by the same number of weaknesses and opportunities. Besides, to enhance the development of coastal tourism enhancement in infrastructure and community involvement is a major subject that must be considered soon. The difference between other research and this research is that the object under study is focused on Wini Beach, North Central Timor Regency. Also, it aims to analyze indicators of coastal tourism, internal and external factors, and strategies for developing coastal tourism on Wini Beach.While other research equations with this study are both aimed at analyzing coastal tourism development strategies and collect data by observation, interviews, and documentation accompanied by using a SWOT analysis.

\section{RESEARCH METHODS}

This study [7] namely the qualitative-quantitative combination method (mixed method) of the Concurrent Triangulation model (a balanced mix of quantitative and qualitative) and the SWOT analysis [7]. This research method is more interesting because researchers can collect two kinds of data (quantitative and qualitative or vice versa) simultaneously, in one data collection stage. Thus, the data obtained will be complete and more accurate. Meanwhile, to formulate a good strategy for the object under study, the researchers used a SWOT matrix analysis. SWOT stands for Internal Strength and Weaknesses environment and External Opportunities and Threats environment. Research respondents totaled 30 people and informants totaled 5 (five) people consisting of local government, managers, and visitors to Wini Beach. Data sources and qualitative data collection methods 
are primary data with purposive sampling and secondary data with documents. Triangulation data collection techniques with primary and secondary sources through observation, interviews, and documentation. Data analysis techniques are pre-field analysis, field analysis (Miles \& Huberman), and SWOT analysis. While data sources and methods of quantitative and SWOT data collection are primary data using incidental sampling and secondary data using documents. Data collection techniques and data instruments using Likert techniques and instruments in the form of a questionnaire. The quantitative data analysis technique is TCR analysis (percentage analysis) and uses the SWOT matrix. The presentation of quantitative and qualitative data in the form of tables [7] with the following figure:

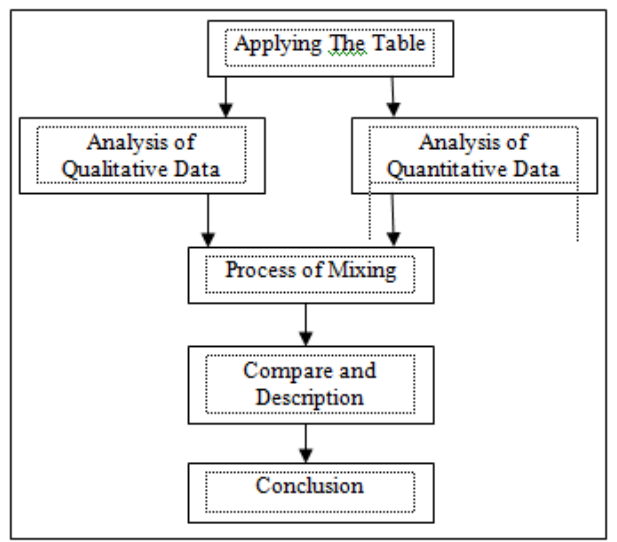

Source: Processed from theory of Creswell [10] and Sugiyono, [7]

\section{RESEARCH FINDINGS}

\section{A. Results of Analysis and Discussion of the Mix Method and SWOT}

1) Environment and ecology: In the Ecological Planning indicators with TCR 3 calculations, the indicators are quite good, namely Pollution Prevention (55-60\%) Environmental Maintenance (54-56\%) Very Low and Ecological Restoration Systems (59-60\%) Low on Planning indicators Ecology (60$65 \%$ ) Fairly Good and Landscape diversity (60-67\%) Fairly Good. For this reason, maintaining the integrity of the ecological system, reducing waste and pollution, reducing the accumulation of plastic waste, restricting access to damaged areas on the coast, encouraging government and academic activities as well as making and maintaining game facilities and photo spots.

2) Economy and development: In 4 indicators get an average score of $70-81 \%$ in good. Local Job Opportunities, Economic Sub-sector, Development of Association Operations and Creative Industry Planning, these are opportunities in developing and creating jobs, providing financial subsidies for residents, encouraging the development of trade and service businesses, supporting coastal activities, and developing the local tourism industry such as homestay, cafe.

3) Society and culture: with an average score not yet good enough (40-55\%) for indicators of infrastructure quality, promotion of conservative concepts, protection of local culture, cultural identity, and human resource training. Need to develop adequate facilities, preservation of local culture, enhancement of local socio-cultural identity and enhancement of human resources.

4) Tourism value creation: with a good average score (70$80 \%$ ) for indicators of the Quality of Tourism Facilities, Tourism Integrated Services, Service Quality, Experience Value and Quality of Creative Tourism Activities. Facility maintenance is needed, improving the quality of guidance, developing service quality services and developing potential tourism creative activities.

5) Management and policy: for Regulatory Formulation indicators (Comprehensive (70-80\%), Control Measures (7577\%), Management Resources (55-60\%), Special Administrative Units (55-60), Budget Allocation (70-80\%) and Local Participation Policies (55-60\%), so that it needs clear regulations, policy controls, training in tourism guides, increasing subsidies of budgets and involvement of residents.

6) Climate conditions: Indicators of Religious Factors (45$50 \%$ ) and Hurricanes (55-60\%) Less Good Need to pay attention to the time of visit.

7) Climate conditions: Indicators of Religious Factors (45$50 \%$ ) and Hurricanes $(55-60 \%)$ Less Good Need to pay attention to the time of visit.

After obtaining the results of the analysis and discussion of the Wini Beach by Mix Method and SWOT, then the strategy formulation in the SWOT matrix as below:

TABLE I. DIAGRAM MATRIX SWOT

\begin{tabular}{|c|c|c|}
\hline & \multicolumn{2}{|c|}{ Matrix SWOT Diagram } \\
\hline & Strength $(S)$ & Weakness $(W)$ \\
\hline & $\begin{array}{l}\text {-The availability of } \\
\text { coastal land for } \\
\text { develop-ment } \\
\text { Natural and cultural } \\
\text { tourism } \\
\text { - The charm of the } \\
\text { country's border } \\
\text { beaches. }\end{array}$ & $\begin{array}{l}\text {-Modes of transportation } \\
\text { Attractions and complete } \\
\text { facilities } \\
\text {-Quality of tourism } \\
\text { human resources }\end{array}$ \\
\hline Opportunity $(\mathrm{O})$ & Strategy SO & Strategy $\mathrm{WO}$ \\
\hline $\begin{array}{l}\text {-Local } \\
\text { Community } \\
\text { Empowerment } \\
\text {-Work } \\
\text { opportunities for } \\
\text { residents } \\
\text {-Cooperation } \\
\text { between } \\
\text { stakeholders } \\
\text { There are } \\
\text { investors } \\
\end{array}$ & $\begin{array}{l}\text {-Use land for coastal } \\
\text { tourism development } \\
\text {-Optimizing } \\
\text { stakeholder } \\
\text { participation to create } \\
\text { local wisdom } \\
\text {-Optimizing the } \\
\text { develop-ment of } \\
\text { coastal tourism } \\
\text { attractions }\end{array}$ & $\begin{array}{l}\text {-Optimizing existing } \\
\text { access with ecosys-tem } \\
\text { preservation programs } \\
\text {-Developing the quality } \\
\text { and character of tourism } \\
\text { human resources } \\
\text {-Development and } \\
\text { routine maintenance of } \\
\text { facilities } \\
\text {-There are promoti-ons at } \\
\text { certain events }\end{array}$ \\
\hline
\end{tabular}


Table 1. Cont.

\begin{tabular}{|c|c|c|}
\hline Threat $(T)$ & Strategy $S T$ & Strategy WT \\
\hline $\begin{array}{l}- \\
\text { (tornado) } \\
\text {-Seasonal factor } \\
\text { (Rain / flood) }\end{array}$ & $\begin{array}{l}\text {-Conserving } \\
\text { mangroves so that } \\
\text { there is a sustainable } \\
\text { coastal ecosystem } \\
\text {-Cooperate with } \\
\text { BMKG, BNPB, and } \\
\text { related offices } \\
\text {-Involvement of the } \\
\text { surrounding in the } \\
\text { community in } \\
\text { management and } \\
\text { development } \\
\text { coastal tourism of }\end{array}$ & $\begin{array}{l}\text {-Improve service and } \\
\text { comfort for tourists } \\
\text {-Optimizing the number } \\
\text { of modes of } \\
\text { transportation } \\
\text {-Refining effective and } \\
\text { efficient coastal tourism } \\
\text { develop-ment strategies. }\end{array}$ \\
\hline
\end{tabular}

\section{CONCLUSIONS AND SUGGESTIONS}

\section{A. Conclusion}

- The understanding of the environment and ecology of Wini Beach is not good enough so that this beach does not focus on fully engaging in this strategy.

- Pantai Wini has not implemented a good economic and development strategy, especially in the indicators of economic subsidies, this can be seen from the absence of financial subsidies for residents.

- Wini Beach has used community and cultural strategies quite well, although not yet maximally, this can be seen from the preservation and enhancement of local culture.

- Wini Beach has not maximally implemented the tourism value creation strategy, this is evidenced by the inadequate quality of tourism facilities and service quality.

- Pantai Wini has implemented management and policies well, this can be seen from its existing policies and or regulations from the local government or management.

- There needs to be assistance and counseling on Climate Awareness

In the SWOT analysis, it was found that the strongest factors that had been carried out for Wini Beach were still some weaknesses. So, it can be concluded that Wini Beach must strengthen the WO strategy, namely taking advantage of opportunities by overcoming weaknesses, namely promoting at certain events, optimizing existing access with ecosystem conservation programs, developing the quality and character of tourism human resources, and developing and maintaining facilities regularly.

\section{B. Suggestion}

Based on the discussion of the research results, recommendations can be given to local governments and managers of Wini Beach to be able to add new strategies that are more effective and efficient, such as focusing on expanding human resource competencies in the tourism sector, preserving environmentally friendly coastal ecosystems, forming an orderly and professional management system, and focus on adding facilities and infrastructure for coastal tourism and their maintenance. Some ways can be done, namely:

- Develop partnerships.

- Managing coastal tourism visitors to Wini Beach.

- Developing coastal tourism products for Wini Beach.

- Developing the coastal tourist attraction of Wini Beach.

- Developing coastal tourism activities at Wini Beach.

- Developing facilities and infrastructure to support Wini Beach tourism.

- Developing Wini Coastal tourism management institutions.

- Planning for the management of the impact of coastal tourism on the Wini coast.

- Developing Wini Coastal tourism marketing.

- It is highly recommended that Wini Beach be conducted a periodic SWOT analysis to determine the level of strengths, weaknesses, opportunities, and threats in internal and external beaches to follow up on the manager's strategy in dealing with every possibility that exists more professionally and as a reformulation of the future Wini Coast coastal tourism development strategy.

\section{REFERENCES}

[1] TTU Regency Tourism Office, 2019.

[2] P. Timmerman, R. White, "Megahydropolis: Coastal Cities in the Context of Global Environmental Change". Global Environmental Change. 7(3), pp. 205 - 234. 1997.

[3] Monavari, Abed, Karbassi, Farshchi, and Abedi IOP Conf. Series: Earth and Environmental Science 202, 2018

[4] K. Larsen et al., 2011;. Sasidharan et al., 2002.

[5] S. Dolnicar, F. Leisch, "Selective marketing for environmentally sustainable tourism". Tourism. Manage. 29(4), pp. 672-680. 2008.

[6] Ch. Lim, M. McAleer, "Ecologically sustainable tourism management environt”. Modell. Softw. 20(11): pp. 1431- 1438. 2005.

[7] Sugiyono, Research of Mix Method. Bandung Alfabeta. 2015.

[8] I. Cahyadinata, "The Suitability Of Coastal Zone Development Of Enggano Island Capture and Fisheries For Tourismp". AGRISEPJournal, 2009, Vol. 9 No. 2Change". Global Environmental Change. 7(3), pp. 205 - 234. 2013.

[9] Commonwealth Coastal Action Program, Coastal Tourism: A Manual for Suistainable Development, Commonwealth of Australia. 1997.

[10] J.W. Creswell, Qualitative Inquiry and Research Design: Choosing Among Five Traditions London. SAGE Publications. 1998. 